www.czasopisma.marszalek.com.pl/pl/10-15804/npw

\title{
PAULA TOMASZEWSKA
}

Uniwersytet im. Adama Mickiewicza w Poznaniu

ORCID ID: https://orcid.org/0000-0003-0583-0938

KRZYSZTOF FiLA

Uniwersytet Wrocławski

ORCID ID: https://orcid.org/0000-0002-8386-1775

\section{Sieć 5G w perspektywie polskich zmian normatywnych}

\section{The 5G Network in the Perspective of Polish Normative Changes}

\section{Abstract}

The article aims to diagnose the potential for introducing 5G in Poland and to review the legal changes that affect the dynamics of the Polish telecommunications market. The authors will try to answer the following questions: how is Poland responding to the USChinese competition for primacy over $5 \mathrm{G}$ technology? What is the technological dilemma of Poland's security? What legal assumptions does Poland intend to adopt in relation to 5G technology? Does the Polish side demonstrate discriminatory actions against any leader in the field of $5 \mathrm{G}$ technology development? One of the conclusions of the article is the statement that $5 \mathrm{G}$ technology will require not only technical or business changes, but above all systemic and legal changes in the Polish social reality will be necessary. In the course of the research precedings the method of critical content analysis was chosen - in the area of political science research, as well as the formal and dogmatic method to penetrate the plane of the binding law. Hence, the combination of the two indicated methods should result in a multifaceted argument covering two research fields indicated in the title.

Keywords: 5G in Poland, 5G technology, Huawei, technological competition, legal changes 


\section{Сеть 5G с точки зрения польских нормативных изменений}

\section{Аннотация}

Статья направлена на диагностику потенциала внедрения 5G в Польше и обзор законодательных изменений, которые влияют на динамику польского телекоммуникационного рынка. Авторы пытаются ответить на следующие вопросы: как Польша реагирует на американо-китайское соревнование за первенство над технологией $5 \mathrm{G}$ ? B чем состоит технологическая дилемма безопасности Польши? Какие правовые предписания Польша намеревается принять в отношении технологии 5G? Проявляет ли польская сторона дискриминационные действия в отношении лидера в развитии технологии 5G? Одним из выводов статьи является утверждение, что технология 5G будет нуждаться не только в технических или бизнес-изменениях, но, прежде всего, будут необходимы системные и правовые изменения в польской социальной действительности. В ходе исследования был использован метод критического контент-анализа - в области политологических исследований, а также формальный и догматический метод проникновения в плоскость обязательного права. Сочетание этих двух методов дает возможность многостороннего аргументирования, охватывающего две области исследования, указанные в заголовке.

Ключевые слова: 5G в Польше, технология 5G, Нuawei, технологическая конкуренция, правовые изменения

\section{Wprowadzenie}

$\bigcirc$ becnie na świecie ma miejsce rywalizacja o przywództwo we wdrażaniu sieci bezprzewodowych piątej generacji, czyli 5G. W przypadku tego pojedynku nie tylko rządy, ale i firmy technologiczne odgrywają znaczącą rolę i stają się podmiotami geopolitycznej gry. Obszarem tej rozgrywki stała się także Polska. W ostatnim czasie chiński lider technologiczny - marka Huawei - znajduje się pod presją wykluczenia w dostawie sieci 5G w Polsce. Wszystko wskazuje na to, że decyzje o tym, jak traktować Huawei w naszym kraju, zostały podjęte w oparciu o silne powiązania sojusznicze z USA. Niegdyś Polska wydawała się balansować pomiędzy naciskami USA a Chinami, jednak obecnie opowiedziała się już zdecydowanie po amerykańskiej stronie.

Artykuł ma na celu diagnozę potencjału wprowadzenia 5G w Polsce oraz przegląd zmian prawnych, które mają wpływ na dynamikę polskiego rynku 
telekomunikacyjnego. Autorzy będą starali się odpowiedzieć na następujące pytania: Jakie założenia prawne Polska zamierza przyjąć względem technologii 5G? Jaki jest technologiczny dylemat bezpieczeństwa Polski? Czy Polska strona przejawia dyskryminujące działania względem jakiegoś lidera w zakresie rozwoju technologii 5G? Jedną z konkluzji płynącą z artykułu jest stwierdzenie, że technologia $5 \mathrm{G}$ będzie wymagać nie tylko zmian technicznych czy biznesowych, ale przede wszystkim konieczne będą zmiany systemowe i prawne w polskiej rzeczywistości społecznej.

W toku badań poprzedzających niniejsze rozważania obrane zostały: metoda krytycznej analizy treści - w obszarze dociekań politologicznych oraz metoda formalno-dogmatyczna dla spenetrowania płaszczyzny prawa obowiązującego. Stąd, zespolenie obu wskazanych metod winno zaowocować wielopłaszczyznowym wywodem, obejmującym wskazane w tytule pole badawcze.

\section{Wdrażanie sieci 5G w Polsce}

W 2017 roku w Polsce rozpoczęły się przygotowania do zapewnienia wszystkim dostępu do Internetu o prędkości przesyłu danych wynoszącej co najmniej $30 \mathrm{Mb} / \mathrm{s}$ (Bieńkowski i in., 2020, s. 245). Cel ten ma być zrealizowany dzięki m.in. sieciom radiokomunikacyjnym standardu piątej generacji (5G). Obecnie technologia 4G/LTE umożliwia przesył 300 megabitów na sekundę. Standard piątej generacji umożliwi przesyłanie 10 tysięcy megabitów (tj. 10 gigabitów) na sekundę, co oznacza ponad 30-krotny wzrost prędkości (Wójcik, 2019). Sieć nowej generacji zwiększy przepustowość i upowszechni dostęp do Internetu oraz zminimalizuje opóźnienia w wymianie danych. W ramach tych działań planowane jest zapewnienie do 2025 roku wszystkim aglomeracjom miejskim i głównym szlakom komunikacyjnym niezakłóconego dostępu do sieci 5G. Należy podkreślić, że sieć 5G jest niezbędnym elementem do wdrożenia i rozwoju technologii Internetu Rzeczy, autonomicznego transportu, przemysłu 4.0, Smart Cities, a także do wystąpienia dalszych przemian cyfrowych. Analitycy Instytutu Kościuszki we współpracy z Fundacją Digital Poland w raporcie pt.: „5G Szanse, zagrożenia, wyzwania”, wydanym na początku maja 2020 roku, wskazują, że 
Technologia 5G będzie kolejną ewolucją w zakresie łączności bezprzewodowej. $\mathrm{W}$ porównaniu z poprzednimi generacjami sieci mobilnych zapewni nawet 20 razy większą prędkość transferu danych (do $10 \mathrm{~Gb} / \mathrm{s}$ przy wysyłaniu oraz do 20 GB/przy pobieraniu), znacznie ograniczy opóźnienia w komunikacji (do jednej milisekundy), a także pozwoli na zwiększenie liczby urządzeń podłączonych do sieci (nawet do miliona urządzeń na kilometr kwadratowy) (Siudak, 2020).

Przedstawiona ikonografia również prezentuje porównanie i ogromny przełom nowej technologii.

\begin{tabular}{llll} 
& & & 2020 \\
\hline
\end{tabular}

Rys. 1. Ewolucja i rozwój sieci mobilnych

Źródło: Ekspertyza. Bariery legislacyjne zwiazane z wykorzystaniem technologii i usług $5 G$ w gospodarce polskiej, s. 23, https://www.il-pib.pl/images/stories/publikacje/Raport_Ekspertyza_5G_EY.pdf.

W styczniu 2018 roku Ministerstwo Cyfryzacji opublikowało Strategię 5G dla Polski, w której można odnaleźć wymienione np. korzyści płynące z wdrożenia tej sieci (Strategia 5G dla Polski, 2018). Także w Strategii Bezpieczeństwa 
Narodowego Rzeczypospolitej Polskiej z 2020 roku odniesiono się do kwestii technologii 5G. W dokumencie podkreślono, że wdrażanie technologii 5G niesie ze sobą szanse dla gospodarki i zagrożenia dla bezpieczeństwa RP. Wobec tego zalecono rozbudowę koniecznej infrastruktury oraz potencjału państwa w kontekście analizowanego obszaru (Strategia, 2020).

Sieć $5 \mathrm{G}$ jest to sieć komercyjna, budowana przez podmioty działające na obszarze Polski. Zyski dla kraju z rozwoju sieci $5 \mathrm{G}$ szacuje się na poziomie 63,2 mld PLN (Grabowski i in., 2019). Znów, według Narodowego Planu Szerokopasmowego, całościowy, kilkuletni koszt może wynieść nawet 20 mld PLN (Narodowy Plan Szerokopasmowy do 2025 r.). Niemniej, należy podkreślić, że Polska ma zaległości w budowie sieci światłowodowej, która odgrywa istotną rolę w tworzeniu sieci 5G. Obecnie pokrycie Polski siecią światłowodową wynosi 79\%, co oznacza, że ponad $1 / 5$ kraju jej nie posiada (Indeks gospodarki cyfrowej..., 2019). Zadaniem administracji państwowej i samorządowej jest stwarzanie odpowiednich warunków do rozwoju tej sieci. Jest ona traktowana jako kluczowa infrastruktura państwa, szczególnie wobec przyjętej już Strategii na Rzecz Odpowiedzialnego Rozwoju (Departament Strategii Rozwoju, 2017).W Polsce niektórzy klienci Orange, Play, Plus oraz T-Mobile mogą już korzystać z nowej sieci 5G. Szacuje się, że do 2028 roku rozwijanie sieci 5G przyniesie Polsce znaczące korzyści, szacowane na poziomie 63,2 mld PLN, które przełożą się także na zwiększenie polskiego PKB o 1,2 proc (Grabowski i in., 2019). Miastem rekomendowanym przez Ministra Cyfryzacji, które jako pierwsze ma otrzymać dostęp do sieci 5G, jest Łódź. Atutem Łodzi jest przede wszystkim lokalizacja, a także fakt, że miasto to wyróżnia się nadal niskim poziomem promieniowania elektromagnetycznego (Grabowska, 2020).

Wprowadzenie technologii 5G oznacza początek nowej ery w łączności, która będzie miała wpływ na prawie każdy element codziennego życia. Możliwe, że 5G przyczyni się do ulepszenia funkcjonowania tak istotnych obszarów jak: edukacja, system ochrony zdrowia, czy też e-administracja. Dzięki sieciom 5G stworzone zostaną warunki do realizacji nowych usług, które m.in. pomogą niwelować nierówności w dostępie do rynku pracy poprzez wsparcie technologiczne pracy zdalnej czy usuwanie barier w dostępie do służby zdrowia poprzez uruchomienie zaawansowanych, zdalnych usług e-zdrowia, wykorzystujących np. aplikacje rozszerzonej rzeczywistości czy 
wirtualnej rzeczywistości (Krawiec i in., 2018). Państwa, które jako pierwsze rozpoczną korzystanie z 5G, mogą utrzymać przewagę konkurencyjną nad pozostałymi (Wilson i in., 2018). Nie można jednak także pominąć obaw społecznych wynikających z wdrażania sieci 5G. W Polsce powstał nawet Raport finansowany przez Narodowy Program Zdrowia, mający ocenić potencjalny wpływ sieci 5G na człowieka (zob. szerz.: Oddziaływanie elektromagnetycznych fal...).

Podkreślenia wymaga jednak fakt, że korzystanie z możliwości sieci 5G nie jest możliwe na terytorium całego państwa. Każdy z operatorów przygotował mapę odnoszącą się do zasięgu swojej oferty (Mieszko, 2020). T. Świderek na łamach Obserwatora Finansowego wskazuje, że:

Uruchamiane tej wiosny w Polsce sieci, a w zasadzie większe lub mniejsze wyspy, na obszarze których dostępne są usługi świadczone w 5G, są co prawda zgodne z branżowym standardem 3GPP, ale korzystają z niewielkich zasobów pasma. To sprawia, że oferowane przez nie parametry - przepływność, popularnie zwana prędkością, oraz opóźnienia - są co najwyżej porównywalne, jeśli nie gorsze od działających już i wykorzystujących agregację kilku odpowiednio szerokich bloków pasma zaawansowanych sieci LTE-A (Świderek, 2020).

Wobec tego należy stwierdzić, że tak naprawdę ocena możliwości tej technologii jest jeszcze niemożliwa.

\section{Polski Krajowy System Cyberbezpieczeństwa}

Komisja Europejska postanowiła uregulować kwestie związane z cyberbezpieczeństwem. Ogólne zalecenia, które są wynikiem konsultacji ze wszystkimi państwami członkowskimi Unii Europejskiej, zostały zapisane w dokumencie 5G Toolbox. Należy podkreślić, że ze strony Polski jako państwa członkowskiego UE, bardzo istotna jest implementacja unijnego Toolboxa 5G, tj. dokumentu wydanego w styczniu 2020 roku przez NIS Cooperation Group, zawierającego zalecenia w zakresie przeciwdziałania ryzykom dla integralności i bezpieczeństwa sieci nowej generacji w Europie (Cybersecurity of 5G..., 2020). Celem tego zestawu narzędzi jest określenie ewentualnego wspólnego zestawu środków, które są w stanie złagodzić główne zagrożenia 
dla cyberbezpieczeństwa sieci 5G, oraz zapewnienie wskazówek dotyczących wyboru środków, którym należy nadać priorytet w planach łagodzenia skutków na szczeblu krajowym i unijnym.

Polskie Ministerstwo Cyfryzacji podkreśla w odpowiedzi na interpelację z 3 kwietnia br. posła na Sejm RP Pana Andrzeja Szejnara w sprawie rozporządzenia dotyczącego budowy sieci 5G (interpelacja nr 4796), że zgodnie z dokumentem Komisji Europejskiej Toolbox 5G, państwa członkowskie powinny dysponować środkami i uprawnieniami w zakresie ograniczania ryzyka w zakresie bezpieczeństwa 5G (Zagórski, 2020).

\section{Projekt ustawy o zmianie ustawy o krajowym systemie cyberbezpieczeństwa z 2020 roku}

Na przełomie 2020 i 2021 roku sporo kontrowersji nie tylko w środowisku dostawców usług telekomunikacyjnych, ale także wśród odbiorców tychże usług, wywołał opublikowany przez Ministerstwo Cyfryzacji projekt ustawy o zmianie ustawy o krajowym systemie cyberbezpieczeństwa (Projekt, 2020). Prawdopodobnie ów stan rzeczy został wywołany przez tę okoliczność, iż obecnie w krajowym systemie cyberbezpieczeństwa nie znajdują się ani przedsiębiorcy telekomunikacyjni, ani tzw. dostawcy usług zaufania, co powoduje, iż jakiekolwiek kroki legislacyjne czynione w tym obszarze stanowią zagospodarowanie od podstaw pola dotychczas prawnie indyferentnego, poprzez nałożenie na wskazane podmioty - do tej pory niewystępujące w takowej przestrzeni prawnej - dodatkowych obowiązków tudzież obostrzeń w ich działalności gospodarczej. Wspomniany projekt co prawda na chwilę obecną nie stał się jeszcze przedmiotem prac legislacyjnych, aczkolwiek nie jest wykluczone, że pomimo uchwalonej w ostatnim czasie stosunkowo wąsko zakrojonej nowelizacji (ustawa z dnia 11 września 2019 roku...) k.s.c. projekt ten pozostanie nadal w orbicie prac ministerialnych tak, by po dalszych konsultacjach branżowych nadany mu został tryb związany właśnie z procesem legislacyjnym. Warto zatem pochylić się nad celami projektu oraz konkretnymi już normatywnymi propozycjami ministerialnymi o tyle, o ile mogą one w niedługim czasie stać się obowiązującym prawem, istotnie rzutującym na rozwój technologii $5 \mathrm{G}$ na terenie Polski. 
W związku z powyższym, badając najpierw wyrażone expressis verbis w uzasadnieniu do projektu motywy zmian ustawowych, należy zwrócić uwagę na ten fragment, który dotyczy koordynacji działań poszczególnych resortów z ogólną polityką Rady Ministrów. Mowa tam jest mianowicie o tym, że:

Projekt ustawy służy realizacji celu Strategii Cyberbezpieczeństwa Rzeczypospolitej Polskiej na lata 2019-2024, jakim jest podniesienie poziomu odporności na cyberzagrożenia oraz poziomu ochrony informacji w sektorach: publicznym, militarnym i prywatnym. Realizuje on także cel szczegółowy w postaci rozwoju krajowego systemu cyberbezpieczeństwa poprzez ewaluację przepisów prawnych dotyczących cyberbezpieczeństwa (Projekt, 2020, s. 29 i 30; zob. też: Tomaszewska, 2020, s. 216-219).

Co więcej, wskazuje się tam też, iż polskie działania winny tak naprawdę stanowić uzupełnienie działań unijnych, albowiem:

Coraz większe znaczenia dla bezpieczeństwa usług kluczowych ma niezawodność usług telekomunikacyjnych. Stacjonarne sieci szerokopasmowe będą uzupełniane przez sieci mobilne nowej generacji (sieci 5G i kolejnych). Polska brała udział w opracowaniu unijnego zestawu narzędzi na potrzeby cyberbezpieczeństwa sieci $5 \mathrm{G}$ (...), w którym zawarto środki na poziomie strategicznym i technicznym oraz wskazano działania wspierające stosowanie tych środków dla ograniczenia ryzyk cyberbezpieczeństwa europejskich sieci 5G (Projekt, 2020, s. 29).

Oznacza to, że każdy z krajów członkowskich musi m.in. dążyć do:

(...) zaostrzenia wymagań w zakresie bezpieczeństwa infrastruktury i usług telekomunikacyjnych, oceniania profili ryzyka dostawców, stosowania odpowiednich ograniczeń w odniesieniu do dostawców stwarzających wysokie ryzyko, w tym niezbędnych wyłączeń w odniesieniu do kluczowych zasobów uznanych za krytyczne i wrażliwe, wdrożenia strategii mających na celu zapewnienie dywersyfikacji dostawców, w celu unikania uzależnienia od dostawców stwarzających wysokie ryzyko (Projekt, 2020, s. 29). 
Tym samym projekt ma stanowić instrument służący realizacji zarysowanych tu celów o tyle, o ile cele te winny zostać przełożone na język ustawy w ten sposób, by całość regulacji k.s.c. stanowiła obszar jednolity pod względem normatywnym.

Niemniej jednak już prima facie wydaje się, że te rozwiązania, które w projekcie klasyfikowane są jako wsparcie dla podmiotów funkcjonujących na rynku telekomunikacyjnym, stanowią jednak istotne ograniczenie dla tychże przedsiębiorców. W związku z tym założenie projektu, iż: „Przedsiębiorcy komunikacji elektronicznej staną się częścią krajowego systemu cyberbezpieczeństwa. Zostanie im udzielone wsparcie $\mathrm{w}$ reagowaniu na incydenty (...)" (Projekt, 2020, s. 30) - jawi się jako nieprzystające do tych rozwiązań, które zostaną niżej pokrótce scharakteryzowane.

W pierwszej kolejności w ramach projektu do k.s.c. miałby zostać dodany przepis art. 66a. ust. 1, o brzmieniu: „Kolegium może sporządzić, na wniosek członka Kolegium, ocenę ryzyka dostawcy sprzętu lub oprogramowania istotnego dla cyberbezpieczeństwa podmiotów krajowego systemu cyberbezpieczeństwa”. Wydaje się, że już samo umiejscowienie tegoż przepisu nie jest trafne o tyle, o ile przepis ten dotyczy zadań Kolegium, nie zaś kwestii czy to ustrojowych (o czym mowa jest w art. 66 k.s.c.), czy też delegacji ustawowych (o czym mowa w art. 67 k.s.c.) (por.: Brzostek, 2019, s. 326), co rodzi konieczność oznaczenia jednostki raczej symbolem „65a” po to, by została zachowana spójność systemowa względem art. 65 k.s.c. Jednakowoż, zważając już tylko na meritum regulacji, można zauważyć, iż: „Nowelizacja przyzna (...) Kolegium do spraw cyberbezpieczeństwa nową kompetencję, jaką będzie możliwość oceny ryzyka dostawcy sprzętu lub oprogramowania istotnego dla cyberbezpieczeństwa podmiotów krajowego systemu cyberbezpieczeństwa" (Projekt, 2020, s. 40-41). Oznacza to, że w kompetencji Kolegium do spraw cyberbezpieczeństwa leżeć będzie wydanie oceny - czy to w odniesieniu do podmiotów krajowych, czy też zagranicznych - w jakim stopniu podmioty te zagrażają polskiemu cyberbezpieczeństwu. Tym sposobem, na zasadzie dodawanego przepisu art. 66 a ust. 5 k.s.c.:

Sporządzona przez Kolegium ocena ryzyka dostawcy sprzętu lub oprogramowania określa: a) wysokie ryzyko, jeżeli dostawca sprzętu lub oprogramowania stanowi poważne zagrożenie dla cyberbezpieczeństwa państwa i zmniejszenie 
poziomu tego ryzyka przez wdrożenie środków technicznych lub organizacyjnych nie jest możliwe, albo b) umiarkowane ryzyko, jeżeli dostawca sprzętu lub oprogramowania stanowi poważne zagrożenie dla cyberbezpieczeństwa państwa a zmniejszenie poziomu tego ryzyka możliwe jest przez wdrożenie środków technicznych lub organizacyjnych, albo c) niskie ryzyko, jeżeli dostawca sprzętu lub oprogramowania stanowi niewielkie zagrożenie dla cyberbezpieczeństwa państwa, albo d) brak zidentyfikowanego poziomu ryzyka, jeżeli nie stwierdzono zagrożenia dla cyberbezpieczeństwa państwa lub jego poziom jest znikomy.

Tylko zaś wydanie oceny w przedmiocie wysokiego stopniu ryzyka rodzi możliwość wszczęcia trybu odwoławczego, sprowadzającego się do ponownego rozpoznania sprawy przez Kolegium do spraw cyberbezpieczeństwa, z tym zastrzeżeniem, że wniesienie odwołania nie będzie miało charakteru suspensywnego (art. 66a ust. 8) ${ }^{1}$. Unormowanie to może budzić uzasadnione obiekcje choćby z tego powodu, iż li tylko represyjność sankcji nie powinna być wystarczającym motywem zarówno niedewolutywności w tym zakresie, jak i natychmiastowego stosowania tychże sankcji, albowiem, jak wskazuje się w doktrynie prawa administracyjnego: „W sprawach dotyczących nałożenia sankcji administracyjnych kryterium pomocnym - zarówno dla ustawodawcy noszącego się z zamiarem umieszczenia w przepisie klauzuli natychmiastowej wykonalności, jak i dla organu stosującego prawo - powinien być charakter konkretnej sankcji (restytucyjny, represyjny, egzekucyjny)" (Kruk, 2010, s. 152-165).

Idąc dalej, bezpośrednie konsekwencje uznania danego dostawcy sprzętu lub oprogramowania za niebezpiecznego występują na dwóch polach - z jednej strony można mówić o sankcjach administracyjnoprawnych, z drugiej strony będą to sankcje gospodarcze, wpisujące się w obszar zamówień publicznych.

Po pierwsze, są to zatem sankcje związane z nakazaniem określonego zachowania się podmiotowi „niebezpiecznemu”, tzn. podmiot ten zobowiązany będzie do: przeprowadzenia szacowania ryzyka związanego ze stosowaniem określonego sprzętu lub oprogramowania i wprowadzenia środków ochrony

1 Rozwiązanie to stoi w sprzeczności z funkcjonującą w polskim postępowaniu administracyjnym ogólną zasadą niewykonywania decyzji nieostatecznych (zob. szerz.: Kędziora, 2016, s. 173-188; Bogusz, 2000, s. 93-102; Augustyńska, 2014, s. 148-184). 
proporcjonalnych do zidentyfikowanych ryzyk, przeglądu planów ciągłości działania i planów odtworzenia działalności pod kątem ryzyka wystąpienia incydentu związanego z daną podatnością, zastosowania określonej poprawki bezpieczeństwa w sprzęcie lub oprogramowaniu posiadającym daną podatność, szczególnej konfiguracji sprzętu lub oprogramowania, zabezpieczającej przed wykorzystaniem określonej podatności, wzmożonego monitorowania zachowania systemu, niekorzystania z określonego sprzętu lub oprogramowania lub też do wprowadzenia reguły ruchu sieciowego zakazującego połączeń z określonymi adresami IP lub nazwami URL (dodane przepisy art. 67c ust. 4 pkt 1 w zw. z art. $67 \mathrm{~b}$ ust. 3 k.s.c.). Co więcej, sankcje te także mogą powodować konieczność: wstrzymania dystrybucji lub zakaz instalacji określonej wersji oprogramowania, zabezpieczenia określonych informacji, w tym dzienników systemowych, a także wytworzenia obrazów stanu określonych urządzeń zainfekowanych złośliwym oprogramowaniem (dodane przepisy art. 67c ust. 4 pkt 2-4 k.s.c.).

Po drugie, niezależnie od powyższych tzw. „poleceń”, w przypadku sporządzenia oceny ryzyka, określającej je jako wysokie, dostarczający sprzęt lub oprogramowanie podmioty krajowego systemu cyberbezpieczeństwa nie wprowadzają do użytkowania sprzętu, oprogramowania i usług, określonych w ocenie danego dostawcy sprzętu lub oprogramowania, tudzież wycofują z użytkowania sprzęt, oprogramowanie i usługi określone w ocenie danego dostawcy sprzętu lub oprogramowania nie później niż 5 lat od dnia ogłoszenia komunikatu o ocenie (dodany przepis art. 66b ust. 1 k.s.c.). W przypadku zaś, gdy ocena określa umiarkowane ryzyko, dostarczający sprzęt lub oprogramowanie podmioty krajowego systemu cyberbezpieczeństwa nie wprowadzają do użytkowania sprzętu, oprogramowania i usług określonych w ocenie danego dostawcy sprzętu lub oprogramowania, natomiast mogą kontynuować użytkowanie dotychczas posiadanych egzemplarzy sprzętu, oprogramowania oraz rodzaju i liczby usług wykorzystywanych przed opublikowaniem komunikatu o ocenie danego dostawcy sprzętu lub oprogramowania (art. 66b ust. 2 k.s.c.).

Po trzecie, ostatni obszar sankcji związany jest z proponowaną nowelizacją unormowań p.z.p. W uzasadnieniu do projektu wskazuje się, iż akt ten: „(...) wprowadza zmiany w przepisach tzw. nowego Prawa Zamówień Publicznych. Wynikają one $\mathrm{z}$ wprowadzenia oceny ryzyka dostawców sprzętu 
i oprogramowania" (Projekt, 2020, 43-44). Projekt wprowadza bowiem dodatkowe kryteria, które dotyczyć będą wymagań, które może wskazać zamawiający w ogłoszeniu o zamówieniu lub dokumentach zamówienia. Mowa jest tu przede wszystkim o wymogu, by dostawca spełniał określony poziom ryzyka według wskazanej wcześniej skali (dodany przepis art. 96 w ust. 2 w pkt 3 p.z.p.). Oznacza to zatem, że dotychczas występujące na gruncie art. 96 p.z.p. wymagania określane przez zamawiającego, obejmujące: aspekty gospodarcze, środowiskowe, społeczne, związane z innowacyjnością, zatrudnieniem lub zachowaniem poufnego charakteru informacji przekazanych wykonawcy w toku realizacji zamówienia, miałyby zostać poszerzone o możliwość wskazania przez zamawiającego także na te kryteria, które bezpośrednio związane byłyby z omówionym już wcześniej poziomem ryzyka, jaki stanowi dostawca sprzętu lub oprogramowania, stwierdzonym oceną sformułowaną przez Kolegium do spraw niebezpieczeństwa. Niezależnie od tego projekt przewiduje też możliwość wykluczenia z zamówienia tego podmiotu, który jest dostawcą sprzętu lub oprogramowania ze stwierdzonym wysokim ryzykiem (dodany przepis 109 w ust. 1 pkt 11 p.z.p.). Niemniej jednak - na co kładzie się nacisk w literaturze przedmiotu - należy mieć przy tym na uwadze, iż: „Analogicznie do przypadku wymogów wynikających z art. 95 ustawy, zamawiający winien pamiętać o konieczności określenia w dokumentach zamówienia, w jaki sposób weryfikować będzie spełnienie określonych w ogłoszeniu o zamówieniu lub dokumentach zamówienia wymogów (...)” (Wiktorowska, 2021, s. 7). Wydaje się to korespondować z przytoczonymi dodatkowymi kryteriami o tyle, o ile pośrednio to także zamawiający będzie w tym przypadku władny dokonywać poniekąd pomiaru stopnia ryzyka, płynącego ze strony danego dostawcy, co czyni spójnym regulacje i projektu i p.z.p.

Kończąc ten wątek, można powiedzieć, iż projekt jest aktem dostosowanym do warunków dynamicznie zmieniającego się obrazu cyberzagrożeń, aczkolwiek poszczególne rozwiązania mogą budzić wątpliwości, po pierwsze, z punktu widzenia dużej dozy uznaniowości przy wydawaniu poszczególnych aktów administracyjnych szeroko ingerujących w swobodę działalności gospodarczej, po drugie - w odniesieniu do poziomu represyjności, które to obostrzenia nierzadko wykluczą podmiot obarczony ryzykiem w ogóle z aktywności gospodarczej na terenie całego kraju. Jednakowoż, być może zmniejszenie stopnia restrykcyjności zasygnalizowanych tu ograniczeń 
mogłoby wpłynąć pozytywnie na polski system cyberbezpieczeństwa w takim zakresie, w jakim swobody wolnorynkowe byłyby ograniczone zachowaniem zasady proporcjonalności, tzn. przy trafnej reakcji na pojawiające się w rzeczywistości pozanormatywnej niebezpieczeństwa (zob. też: Chwała, 2009, s. 427-436).

\section{Reakcja na projekt ustawy o zmianie ustawy o krajowym systemie cyberbezpieczeństwa z 2020 roku}

Proponowane zmiany prawne nie spotkały się z aprobatą zarówno operatorów telekomunikacyjnych, jak i wielu organizacji związanych w różnym stopniu z przemysłem technologicznym. Najwięcej strat w związku z sytuacją Huawei w Polsce poniosłoby przedsiębiorstwo Play.W oficjalnym komunikacie Rada Dyrektorów Play Communications przedstawiła szacunki dotyczące wpływu możliwych ograniczeń dla firmy Huawei we wdrażaniu usług $5 \mathrm{G}$ przez operatora. Play przewiduje, że maksymalny zakres ograniczeń w siedmioletniej perspektywie pociągnie za sobą dodatkowe łączne inwestycje w wysokości około 0,9 mld PLN (Play bez Huaweia?..., 2020). R. Hordyński, dyrektor ds. inwestycji, strategii i komunikacji w firmie Huawei Polska, w wywiadzie dla TelkoIn ocenił, że całkowity koszt wymiany infrastruktury to nawet $15 \mathrm{mld}$ zł (Zatoński, 2020).

Swoje zastrzeżenia zgłosiło również Ministerstwo Sprawiedliwości, które nie chce, żeby oceniany był konkretny dostawca, a wyłącznie jego produkty. Narodowy Bank Polski ostrzegł w swojej opinii, że nowelizacja ustawy zagraża niezależności banku (Boroń, 2020). Krajowa Izba Gospodarcza Elektroniki i Telekomunikacji zauważa również, że zmiany w omawianym projekcie na obecnym etapie procesu legislacyjnego zostały wprowadzone bez zachowania podstawowych zasad transparentności. Podważa to także podstawowe zasady konstytucyjne, a tym bardziej zasadę demokratycznego państwa prawa i zaufania obywateli do organów władzy publicznej (Kozłowski, 2020).W skonstruowanym przez ów podmiot uzasadnieniu stanowiska w omawianej sprawie można przeczytać, iż:

Należy podkreślić, że na obecnym rynku wielu dostawców funkcjonuje w modelu zintegrowanym pionowo (np. Samsung, Huawei), w którym dostarczane przez nich 
rozwiązania funkcjonują w różnych obszarach sieci i mają zróżnicowany wpływ na bezpieczeństwo sieci i usług. Przykładowo, jeden dostawca może być producentem zarówno terminali użytkownika, jak również inwerterów elektrycznych w instalacjach fotowoltaicznych przy stacjach bazowych, infrastruktury radiowej oraz oprogramowania w sieci szkieletowej. Każdy z tych elementów powinien być oceniany z punktu widzenia roli, jaką pełni w świadczeniu usług telekomunikacyjnych, a nie z punktu widzenia rodzaju dostawcy (Kamiński, 2020).

Co oczywiste, swój sprzeciw alarmowały także środowiska chińskie, takie jak: Polsko-Chińska Główna Izba Gospodarcza (SINOCHAM), podkreślając, że dojdzie do naruszenia zasad uczciwej konkurencji, bo, jeśli nowe przepisy zostaną przyjęte, Kolegium uzyska de facto prawo wyboru dostawców, a rynek komercyjny będzie podlegał politycznej ingerencji. Dodano, że obecnie jest tylko trzech głównych dostawców sprzętu 5G. Ograniczenie do tylko jednego $\mathrm{z}$ nich spowoduje stłumienie konkurencji na rynku ICT i negatywnie wpłynie na rozwój branży (Peidong, 2020).

Marka Huawei rozszerzyła swoją działalność w Polsce w 2017 roku. Produkty i usługi Huawei docierają do milionów lokalnych mieszkańców, m.in. dzięki współpracy z dostawcami, takimi jak P4, Orange, T-Mobile i Polkomtel. Huawei wniósł znaczący wkład w polską gospodarkę w ciągu ostatnich pięciu lat, prowadząc działalność lokalną i zaopatrując się u polskich dostawców. Jak wynika z tegorocznej edycji raportu The Economic Impact of Huawei, wkład marki Huawei w 2019 roku do polskiego PKB wynosił 94,9 mln euro. Dla porównania w 2015 roku wynosił 44,7 mln euro, co odpowiada średniorocznemu wzrostowi o 20,7\%. Także zakupy Huawei w Polsce znacznie wzrosły w ciągu ostatnich pięciu lat - w porównaniu z 25,1 mln EUR w 2015 roku w 2019 roku było to już 115,8 mln EUR. Stanowiło to 1,4\% zamówień Huawei w Europie (The economic impact, 2020). Również zaangażowanie tej firmy w badania i rozwój oraz innowacyjność jest obecne w Polsce. Na przykład Huawei utworzył w Warszawie centrum badawczo-rozwojowe i zorganizował w stolicy konferencję Developer Day. Ponadto w październiku 2019 roku ogłoszono, że Huawei zainwestuje 10 mln USD w rozwój własnego „ekosystemu” w Polsce. Przeprowadził także szóstą edycję „Ziarna przyszłości” wraz z sześcioma polskimi uczelniami i czterema patronami. Współpracował chociażby z Politechniką Poznańską 
i ogłosił konkurs wspierający zaangażowanie w ICT, w którym wzięło udział 100 studentów (PP rozwija współpracę z Huawei, 2019).

Próby faktycznego wyeliminowania bądź wyraźnego ograniczenia udziału koncernu Huawei w tworzeniu polskiej infrastruktury 5G wywołały także jawne oburzenie chińskiego potentata. Huawei skierował oskarżenia pod adresem Polski do Komisji Europejskiej, uważając, że Polska kieruje się stronniczymi kryteriami w sprawie wykluczania dostawców w obszarze 5G. Zdaniem koncernu państwo faworyzuje priorytety bezpieczeństwa narodowego USA nad politykę UE. Oskarżenia te są wynikiem tego, że Warszawa podpisała porozumienie w sprawie bezpieczeństwa $5 \mathrm{G}$ z Waszyngtonem (Memorandum of understanding on $5 \mathrm{G}$ security - MoU), którego założeniem jest wykluczenie dostawców na podstawie stronniczych i niejednoznacznych kryteriów ze względu na ich pochodzenie geograficzne. Polska została przedstawiona przez Huawei jako państwo, które narusza fundamentalne zasady UE, zwłaszcza w kontekście niedyskryminacji, będącej jednym z dwóch filarów budowania europejskiej suwerenności technologicznej. Huawei podkreśla, że Polska jako państwo członkowskie musi spełniać wymogi stawiane przez wspólnotę i przestrzegać obowiązującego prawa, które ma pierwszeństwo przed prawem krajowym. Warto sprawić, aby wprowadzone w Polsce rozwiązania uwzględniały interesy państwa, UE oraz były akceptowalne dla USA. Pismo Huawei, uderzające w Polskę, nie bez powodu było skierowane do M. Vestager, ponieważ to Komisja Europejska koordynuje wdrażanie nowych zasad bezpieczeństwa 5G w całej Unii Europejskiej. Wspólnotowy organ rzeczywiście nie posiada mocy powstrzymywania państw przed podejmowaniem daleko idących środków bezpieczeństwa, jednak może interweniować, gdy rządy narzucą prawo telekomunikacyjne, które narusza przepisy unijne (Palczewski, 2020).

W Polsce Huawei - wedle wcześniej zarysowanych uwarunkowań omawianego projektu - prawdopodobnie zostanie sklasyfikowany jako dostawca „umiarkowanego ryzyka”, co oznacza, że operatorzy nie będą mogli kupować od niego nowych dostaw, ale nie będą musieli wymieniać sprzętu. Jednakże ostateczne decyzje nie zostały jeszcze podjęte. Ministerstwo Cyfryzacji zaproponowało stronie chińskiej przeprowadzenie pierwszych Polsko-Chińskich Konsultacji Cyfrowych, mających stanowić podstawę pogłębionego międzyresortowego dialogu, poruszającego szeroki zakres aspektów współpracy 
w obszarze cyfryzacji (Ruszkiewicz, 2020). Nie od dziś wiadomo, że Chiny traktują każdy przypadek wykluczenia Huawei jako sprawę wagi państwowej.

\section{Zakończenie}

Podsumowując powyższe rozważania, należy stwierdzić, że, wdrażanie w Polsce sieci 5G stanowi zjawisko zarówno gospodarcze, jak i polityczne, czy też w końcu prawne. Szeroki zakres społecznego oddziaływania wdrażanych lub planowanych zmian wywołany jest może nie tyle innowacyjnością nowej technologii, ile potencjalnymi korzyściami dla tych podmiotów, które będą w stanie - albo z racji politycznych, albo też kroczących za nimi racji prawnych - przejąć dla siebie rynek, przy zapewnieniu eliminacji potencjalnych współkonkurentów. Wydaje się, że to właśnie z tych, czysto komercyjnych powodów, wielu przedsiębiorców z branży telekomunikacyjnej dotychczas negatywnie wypowiedziało się na temat proponowanych zmian legislacyjnych w obszarze $5 \mathrm{G}$, albowiem nie da się ukryć, iż każde ograniczenie działalności gospodarczej - niezależnie od motywów związanych np.li tylko z cyberbezpieczeństwem - stanowi przejaw ingerencji sił politycznych w te mechanizmy, które kształtują wolny rynek, funkcjonujący dotychczas w sposób najbardziej zbliżony do modelowego.

Wywód, poprzedzony wcześniejszymi badaniami zogniskowanymi zarówno wokół krytycznej analizy treści, jak i dociekań formalno-dogmatycznych, potwierdza w znacznym stopniu wskazaną na wstępie hipotezę, wedle której technologia $5 \mathrm{G}$ będzie wymagać nie tylko zmian technicznych czy biznesowych, ale przede wszystkim konieczne będą zmiany systemowe i prawne w otaczającej nas rzeczywistości społecznej. Wielopłaszczyznowość przeprowadzonych tu badań zdaje się weryfikować te uwarunkowania sieci 5G, które sprawiają, że namnażające się na tym polu problemy nijak nie mogą być rozstrzygane wyłącznie w orbicie spojrzenia czy to czysto normatywistycznego, czy też politologicznego. Niemniej, postępująca technologizacja także i Polski wymaga, by wszystkie te wątki zespolone zostały w jeden spójny obraz i to już w niedalekiej perspektywie czasowej. 
MGR PAULA TOMASZEWSKA

Zakład Studiów Strategicznych

Wydział Nauk Politycznych i Dziennikarstwa

Uniwersytet im. Adama Mickiewicza w Poznaniu

ul. Uniwersytetu Poznańskiego 5, 61-614 Poznań

paula.tomaszewska@amu.edu.pl

\section{MGR KRZYSZTOF FILA}

Katedra Prawa Karnego Materialnego

Wydział Prawa, Administracji i Ekonomii

Uniwersytet Wrocławski

ul. Uniwersytecka 22/26, 50-145 Wrocław

krzysztof.fila@uwr.edu.pl

\section{Bibliografia}

Augustyńska, B. (2014). Kilka uwag o rygorze natychmiastowej wykonalności decyzji (na przykładzie Kodeksu postępowania administracyjnego i Ordynacji podatkowej). Administracja, 4, 148-184.

Bieńkowski, P. i in. (2020). Uwarunkowania ekspozycji ludności na pole elektromagnetyczne związane $\mathrm{z}$ użytkowaniem radiokomunikacyjnych sieci w technologii 5G w Polsce. Medycyna Pracy, 71(2), 245-253.

Bogusz, M. (2000).W sprawie pojęcia wykonalności decyzji administracyjnej. Gdańskie Studia Prawnicze, 7, 93-102.

Boroń, M. (2020, 20 października). NBP: projekt ustawy o cyberbezpieczeństwie może naruszać niezależność banku centralnego. Bankier.pl. Pobrane z: https://www.bankier.pl/wiadomosc/NBP-projekt-ustawy-o-cyberbezpieczenstwie-moze-naruszac-niezaleznosc-banku-centralnego-7984662.html.

Brzostek, A. (2019). Pełnomocnik i Kolegium. W: W. Kitler, J. Taczkowska-Olszewska, F. Radoniewicz (red.). Ustawa o krajowym systemie cyberbezpieczeństwa. Komentarz (326). Warszawa: C.H. Beck.

Chwała, K. (2009). Bezpieczeństwo informacji w unormowaniach prawnych. W: T. Jemioła, J. Kisielnicki, K. Rajchela (red.). Cyberterroryzm - nowe wyzwania XXI wieku. Warszawa: Wydział Wydawnictw i Poligrafii Wyższej Szkoły Policji w Szczytnie.

Cybersecurity of 5G networks EU Toolbox of risk mitigating measures (2020, 29 stycznia). NIS Cooperation Group. Pobrane z: https://ec.europa.eu/digital-single-market/ en/news/cybersecurity-5g-networks-eu-toolbox-risk-mitigating-measures. 
Departament Strategii Rozwoju, Strategia na Rzecz Odpowiedzialnego Rozwoju do roku 2020 (z perspektywą do 2030 r.). (2017). Pobrane z: https://www.gov.pl/documents/33377/436740/SOR.pdf.

Grabowski, T. i in. (2019). Sieci 5G w Polsce. Szanse i wyzwania. Accenture. Pobrane z: https://www.accenture.com/_acnmedia/Accenture/Redesign-Assets/DotCom/ Documents/Local/2/Accenture-Report-Web-5G-Poland-Chances-Challenges. pdf\#zoom $=50$.

Grabowska, M. (2020). Europejskie społeczeństwo gigabitowe. Studia Europejskie - Studies in European Affairs, 1 .

Indeks gospodarki cyfrowej i społeczeństwa cyfrowego (DESI). Sprawozdanie krajowe na rok 2019. (2019). Pobrane z: https://ec.europa.eu/digital-single-market/en/ scoreboard/poland.

Kamiński, S. (2020, 6 października). Stanowisko - Krajowej Izby Gospodarczej Elektroniki i Telekomunikacji. Pobrane z: https://kigeit.org.pl/FTP/ap/sot/201006_out_ MC_stan_KSC.pdf, 16-17.

Kozłowski, A. (2020, 28 października). Rząd ma zamiar złagodzić swoje stanowisko wobec Huawei i zrezygnować z części zapisów ustawy o Krajowym Systemie Cyberbezpieczeństwa, które mogłyby być wymierzone w chińskiego giganta - informuje Wirtualna Polska. Cyberdefence24.pl. Pobrane z: https://www.cyberdefence24.pl/ polski-rzad-wyciaga-reke-w-strone-chin-huawei-nie-zostanie-wykluczony.

Kędziora, R. (2016). Natychmiastowa wykonalność nieostatecznej decyzji administracyjnej. Metryka, 1, 173-188.

Kruk, E. (2010). Z problematyki wykonania decyzji o nałożeniu sankcji administracyjnej. Administracja, 3, 152-165.

Krawiec, P. i in. (2018). Instytut Łączności wobec wyzwań związanych z wdrażaniem sieci 5G w Polsce. Telekomunikacja i techniki informacyjne, 1-2, 41.

k.s.c. Ustawa z dnia 5 lipca 2018 r. o krajowym systemie cyberbezpieczeństwa (Dz.U. z 2020 r., poz. 1369, z późn. zm.).

Mieszko, T. (2020, 14 sierpnia).Wszyscy polscy operatorzy uruchomili już sieć 5G. Zobacz mapę zasięgu. Komputer Świat. Pobrane z: https://www.komputerswiat.pl/artykuly/redakcyjne/wszyscy-polscy-operatorzy-uruchomili-juz-siec-5g-zobacz-mape-zasiegu/ c83hlb6.

Narodowy Plan Szerokopasmowy do 2025 r. Pobrane z: https://www.gov.pl/web/ cyfryzacja/narodowy-plan-szerokopasmowy--- zaktualizowany.

Oddziaływanie elektromagnetycznych fal milimetrowych na zdrowie pracowników projektowanych sieci 5G i populacji generalnej. Narodowy Program Zdrowia. Pobrane z: http://www.imp.lodz.pl/upload/npz/raport_5g.pdf.

Palczewski, Sz. (2020, 2 listopada). Huawei walczy o pozostanie „w grze” na rynku UE. Polska i Rumunia oskarżone o faworyzowanie USA. CyberDefence24. Pobrane z: https://www.cyberdefence24.pl/huawei-walczy-o-pozostanie-w-grze-na-rynku-ue-polska-i-rumunia-oskarzone-o-faworyzowanie-usa.

Peidong, G. (2020, 8 października). Opinia Polsko-Chińskiej Głównej Izby Gospodarczej w sprawie projektu ustawy zmieniającej Ustawę o krajowym systemie cyberbezpieczeństwa. SINOCHAM. Pobrane z: https://sinocham.pl/aktualnosci/opinia-pol- 
sko-chi\%C5\%84skiej-g\%C5\%82\%C3\%B3wnej-izby-gospodarczej-w-sprawie-projektu-ustawy.

Play bez Huaweia? Pozbycie się chińskiej marki tańsze niż szacowano (2020, 16 września). Telepolis. Pobrane z: https://www.telepolis.pl/wiadomosci/prawo-finanse-statystyki/ siec-play-bez-sprzetu-huawei-operator-policzyl-ile-to-bedzie-kosztowalo.

Projekt (2020). Projekt z dnia 7 września 2020 r. ustawy o zmianie ustawy o krajowym systemie cyberbezpieczeństwa oraz ustawy - Prawo zamówień publicznych z uzasadnieniem. Pobrane z: https://mc.bip.gov.pl/projekty-aktow-prawnych-mc/ projekt-ustawy-o-zmianie-ustawy-o-krajowym-systemie-cyberbezpieczenstwa-oraz-ustawy-prawo-zamowien-publicznych.html.

PP rozwija współpracę z Huawei (2019, 5 czerwca). Politechnika Poznańska. Pobrane z: https://www.put.poznan.pl/pl/aktualnosc/pp-rozwija-wspolprace-z-huawei.

p.z.p. Ustawa z dnia 11 września 2019 r. - Prawo zamówień publicznych (Dz.U. z 2019 r., poz. 2019).

Ruszkiewicz, S. (2020, 28 października). Rząd nie wyrzuci Huawei z Polski? Nagły zwrot ws. antychińskiego prawa. Wirtualna Polska. Pobrane z: https://wiadomosci. wp.pl/rzad-nie-wyrzuci-huawei-z-polski-nagly-zwrot-ws-antychinskiego-prawa-6569196280990400 a.

The economic impact of Huawei in Poland (2020 listopad). Oxford Economics. Pobrane z: https://www.oxfordeconomics.com/recent-releases/The-Economic-Impact -of-Huawei-in-Europe.

Tomaszewska, P. (2020). Cyberterroryzm jako wyzwanie dla bezpieczeństwa infrastruktury krytycznej w świetle polskiej strategii cyberbezpieczeństwa RP na lata 2019-1924. W: K. Śmiałek (red.). Zarządzanie kryzysowe wobec wyzwań i zagrożeń dla bezpieczeństwa wewnętrznego państwa. Warszawa.

Siudak, R. i in. (2020). 5G Szanse, zagrożenia, wyzwania. Instytut Kościuszki. Fundacja Digital Poland. Pobrane z: https://www.digitalpoland.org/assets/publications/ 2020-5g-szanse-zagrozenia-wyzwania/2020-5g-szanse-wyzwania-zagrozenia.pdf. Strategia Bezpieczeństwa Narodowego Rzeczypospolitej Polskiej. BBN. Warszawa 2020. Strategia 5G dla Polski. (2018). Ministerstwo Cyfryzacji. Pobrane z: https://www.gov. $\mathrm{pl} /$ documents/31305/436699/Strategia+5G+dla+Polski.pdf/0cd08029-2074be13-21c8-fc1cf09629b0.

Świderek, T. (2020, 9 lipca). Polska droga do 5G. Obserwator Finansowy. Pobrane z: https://www.obserwatorfinansowy.pl/bez-kategorii/rotator/polska-droga-do-5g/.

Ustawa z dnia 11 września 2019 r. - Przepisy wprowadzające ustawę - Prawo zamówień publicznych (Dz.U. z 2019 r., poz. 2020).

Wiktorowska, E. (2021). Komentarz do art. 96. W: A. Gawrońska-Baran, A. Wiktorowski, P. Wójcik, E. Wiktorowska (red.). Prawo zamówień publicznych. Komentarz. Warszawa: System Informacji Prawnej LEX.

Wilson, P. i in. (2018). 5G: The chance to lead for a decade. Deloitte. Pobrane z: https://www2.deloitte.com/content/dam/Deloitte/us/Documents/technology-media-telecommunications/us-tmt-5g-deployment-imperative.pdf? $\mathrm{mod}=$ article_inline\&eminfo=\%7b $\% 22$ EMAIL $\% 22 \% 3 a \% 2281 \mathrm{q} 6 \mathrm{mHUHC}$ q $\% 2 \mathrm{~b} 80 \mathrm{H} 9 \mathrm{Uub}$ F3lRYfqTVf7fO $\% 22 \% 2$ c\%22BRAND $\% 22 \% 3 a \% 22 F O \% 22 \% 2 c \% 22 \mathrm{C}$. 
Wójcik, P. (2019, 13 listopada). Czy sieć 5G w Polsce to niebezpieczeństwo? [wyjaśniamy]. Krytyka Polityczna. Pobrane z: https://krytykapolityczna.pl/gospodarka/ wojcik-siec-5g-w-polsce-wyjasniamy/.

Zatoński, M. (2020, 13 sierpnia). Huawei Polska: zastąpienie nas kosztowałoby miliardy. Puls Biznesu. Pobrane z: https://www.pb.pl/huawei-polska-zastapienie -nas-kosztowaloby-miliardy-999344.

Zgórski, M. (2020, 6 maja). Interpelacja nr 4796 w sprawie rozporządzenia dotyczącego budowy sieci 5G. Strona internetowa Sejmu RP. Pobrane z: http://orka2.sejm.gov.pl/ INT9.nsf/klucz/ATTBPEJ2R/\%24FILE/i04796-o1.pdf. 